\title{
The Conflict in Tigray and its Challenges for Sustainable Peace between Eritrea and Ethiopia
}

\author{
Aklilu Gebretinsae Andemikael \\ PhD Candidate, Department of International Relations, School of International and Public Affairs, Jilin University, People's \\ Republic of China
}

\begin{abstract}
This research article argues that a peaceful settlement of the conflict in Tigray is crucial for the continuation of the peace process, and is decisively linked with the attainment of sustainable peace between Eritrea and Ethiopia. For the conflict has an intra-state and inter-state dimension, any would be solution has for all intents and purposes to be an all-inclusive and sustainable. The TPLF has become 'mutually exclusive' with all participants in the conflict namely the Federal Government of Ethiopia, the Amhara Regional State Government as well as the Government of the State of Eritrea. By identifying the genesis, development and the substantive reasons for the continuation of the conflict, this research concludes that the preconditions for sustainable peace are unfortunately missing.
\end{abstract}

Key Words: Eritrea; Ethiopia; peace process; security dilemma; sustainable peace; Tigray

\section{THE GENESIS AND THE DEVELOPMENT OF THE CONFLICT}

A bout the contagious nature of domestic conflicts, Nagar and Paterson warn that there is a possibility of a spillover of conflicts into neighboring countries. And for that reason, it is far-fetched to attempt to accomplish peace building in one country in isolation (D. Nagar and M. Paterson, 2012). The genesis of the current conflict in Northern Ethiopian region of Tigray is multi-pronged and can be seen from two levels: an intrastate (as a domestic issue of Ethiopia) and an interstate (as a conflict between Eritrea and Ethiopia). In order to understand the aspect of intra-state level source of the conflict, there is a need to examine the state-society relations in the history of Ethiopia. Ethiopia, after its formation in the second half of the $19^{\text {th }}$ Century, the country had been under consecutive unitary systems. And those unitary governments were allegedly dominated by the Amhara ethnic group. After the change of Government in 1991, the TPLF-led regime came with a new constitution that endorsed an ethnic-based federal arrangement 'as a panacea to a century-long contesting identity of the Ethiopian state.' Because of that, the former provinces in Ethiopia were restructured according to the much-contested linguistic identities.

Though a unitary and highly centralized system was not a solution to the nation-building and state-building equation of the enormously heterogeneous Ethiopian state, neither did the ethnic-based federal system solve the century-long problems of the conflict-ridden Ethiopian state. As the proponents of ethnic-based federalism would advocate, such an arrangement might have alleviated some of the problems. For example, some ethnic groups have been able to express their cultural identities and use their respective languages for education and administrative purposes.

On the other side, the opponents of the ethnic-based federal arrangement consistently argue that the most negative side of such federal arrangement is that ethnic groups started to prioritize their secondary identity (ethnicity) upon their primary identity (national identity). Obsessions with provincial borders (kilil) became too pronounced, and ethnicrelated conflicts became pervasive. Many opponents of the ethnic-based federal system unambiguously argued that such arrangement has encouraged citizens of the country 'to think in terms of ethnic identity rather than a citizenship-based civic identity.' Furthermore, this resulted in the rising of "ethnic consciousness and a weakening of pan-Ethiopian identity". (Temesgen K, 2021). Besides, the TPLF-led regime became authoritarian and conflict-ridden. Furthermore, the aboveenumerated resentments cumulatively resulted in the vertical polarization of ethnic groups in Ethiopia.

As a result, post-1991 Ethiopia gradually became among the few countries in the world where inter-state boundaries are given almost equal primacy to international borders. This mentality is much prevalent in Tigray than in any other region in Ethiopia. In the years during which the TPLF dominated Ethiopia (between 1991-2017), it ruled the country with utmost political and security dominance and with the alleged incorporation of vast swaths of lands of Wolkait and Raya areas into Tigray that belonged to the Amhara ethnic group. These areas are now equally being claimed by both the Amhara and the Tigray ethnic groups, elevating the issue of territory to an 'interstate' level and further making peaceful settlement very complicated.

On one side, to understand the inter-state level of the current complex problems, it is imperative to briefly evaluate the pre1991 relations between the then Eritrean People's Liberation Front (EPLF) and the then TPLF. And on the other side, there is a need to examine the 1991-2018 relations between the essentially EPLF-led Government of Eritrea and the TPLFdominated Government in Ethiopia.

When the 1998 bloody border conflict between Eritrea and Ethiopia broke out, it became clear that both EPLF and TPLF, contrary to what it seemed for many, didn't have such a friendly relationship among themselves. Instead, they had visible differences and sporadic misunderstandings on many 
issues. Nevertheless, for pragmatic reasons, they opted mutual cooperation in their fight against a common enemy i.e., the military regime dictated by Col. Mengistu Hailemeriam. During the pre-1991 period of intermittent cooperation and confrontation between EPLF and TPLF, the border issue between Eritrea and Tigray was crucial for the TPLF as to where the 'international border' of Tigray would lie. Hence, what surfaced as a border conflict between TPLF's Ethiopia and the state of Eritrea in 1998 was not at all accidental, but besides other issues, it was mainly the outgrowth of TPLF's previous obsessions with the borders of its imagined 'Republic of Greater Tigray.' That is why the problems generated from the deficiency of the ethnic-based federal arrangement that the TPLF primarily designed spills over the relation between Eritrea and Ethiopia and has a dimension of both an intra-state and an interstate level of repercussions.

As will be elucidated further, many factors contributed to the current crisis in Tigray. After the change of Government in Ethiopia, many concerns popped up both within Ethiopia as well as to the peace process between Eritrea and Ethiopia. In order to understand the current intricate situation in Tigray, it is pertinent to see the alignments and realignments that emerged after the advent of a new government in Ethiopia on one side and between Eritrea and Ethiopia on the other side.

There are three worth explaining aspects of the development of the current crisis. Firstly, after losing the 27 years of its grip on power, the TPLF was driven out of Addis Ababa and retreated into its home-region Tigray. The new Government of Prime Minister Abiy Ahmed came up with policies of rapprochement towards Eritrea and also introduced drastic reforms within Ethiopia. Both initiatives were seen with suspicion by the TPLF.TPLF's post-2018 relations with the Federal Government were essentially confrontational and recognizably on their lowest ebb. The TPLF-led Regional State Government grumbled with "ethnic marginalization and economic sabotage". (Yonatan T.F., 2020). And in December 2019, the new Government of Prime Minister Abiy dismantled the party system introduced by TPLF (ACLED, 2021) and came up with a new party named Prosperity Party (PP). The dismantlement of the Ethiopian People's Revolutionary Democratic Front (EPRDF) has been done with disregard to the objections from the TPLF. The TPLFdominated EPRDF Coalition government supported what it calls 'Revolutionary Democracy' - an ideology of state-led approach to development. Hence, TPLF, in principle, would not be voluntary to join the newly established PP because the PP emphasizes economic liberalization - an ideology that cannot be reconciled with EPRDF's ideology.

After it retreated to Tigray, the TPLF gradually became a 'quasi-independent government. When the outright conflict of November 2020 broke out, the TPLF had already trained military forces of 250,000 of well-armed militia and Special Forces (Yonatan T.F, 2020) and possessed significant hardware. (M. Plaut, 2021). The highest peak of the discord that led to an almost rupture of relations between the two sides surfaced when on March 1, the National Electoral Board of Ethiopia declared that national and regional elections had been postponed due to the outbreak of the Corona virus. This decision for the postponement of the election had to be reached in consensus with all pro-government as well as opposition parties, including the TPLF. The Tigray Regional State Government interpreted the deferment of the elections as unconstitutional and autocratic (Reuters, 2020) and unilaterally conducted an election by August 2020, "paving the way to Constitutional Conundrum." (Yonatan T. F, 2020). Yonatan argues that there was a possibility of solving the confrontation between the Federal Government and the Tigray Regional State Government had the two sides engaged in "intergovernmental dialogue" (Yonatan T. F, 2020) to iron out their differences.

Secondly, the already unhealthy relations between the Tigray and Amhara Regional State Governments became discernibly combative because the former had already lost almost all the leverages it enjoyed for decades in Ethiopian politics. The latter showed visible alignment with the new Government of Prime Minister Abiy. This new development boosted the decade's long desire of the Amhara to regain 'the territories lost to Tigray.' In view of the TPLF-led Tigray Regional State Government, this move was seen essentially as a result of 'a deliberate appeasement of the Federal Government to the provocative claim of the Amhara region over the historical lands of Tigray known as Wolkait and Raya.'

Thirdly, and very importantly, TPLF's stance on how the border issue with Eritrea should be solved never changed. The TPLF-led Ethiopian Government, when it was in power, rejected the Eritrean Ethiopian Border Commission (EEBC) decision of April 13, 2002 that Badme (the flashpoint of the conflict) belonged to Eritrea. The TPLF-led Ethiopian Government rejected and obstructed the finalization of the demarcation and designed the so-called 'no war, no peace' foreign policy towards Eritrea. Since then, the border problem remained in limbo for the TPLF-led Ethiopian Government "neither allowed physical demarcation nor accepted the virtual demarcation". (Kidane M, 2011).The TPLF-led Ethiopian Government was also instrumental when the unfair sanction imposed on Eritrea, a sanction imposed on Eritrea on the pretext of its alleged connection with Alshebab - a terrorist group organization based in Somalia. Eventually, the allegation was proved to be fictitious, and finally was lifted after the advent of Prime Minister Abiy on power.

The 2018 Peace Agreement was expected to solve the border conflict and cooperation between Eritrea and Ethiopia. Nevertheless, to the dismay of many, the Peace Agreement and other domestic reforms in Ethiopia led to the development of a security dilemma within the TPLF leadership. The TPLFled Regional State Government, despite it lost the crucial power it had in the Ethiopian politics, was resolutely involved in sending a message that 'it was a force that should not be ignored in the finalization of the demarcation of the border between Eritrea and Ethiopia.' Not only that, it also visibly 
obstructed the withdrawal of the Ethiopian National Defense Forces (Northern Command) from the Eritrean territories that were occupied during the two years border conflict of 19982000. Finally, the TPLF declared that any demarcation of the border could not be executed without the consent of the Tigray Regional State Government.

The above moves had two basic repercussions. For the Government of the State of Eritrea, these moves by the TPLF were equivalent to declaring 'no peace, but war'. And for the Federal Government of Ethiopia, a clear disregard of its vested sovereign power to exercise its exclusive jurisdiction on national issues in general and national security related issues in particular. The TPLF, based on the principle of 'the friend of my enemy is my enemy', it equally tarnished the two governments of Eritrea and Ethiopia as 'enemies'. And its relation with the Amhara Regional State Government correspondingly grew aggressive. Security dilemma started to take its stage in the TPLF camp.

In the rest of Ethiopia, the animosity against the TPLF and also against ethnic Tigrayans heightened. (Ahmed S, 2019) observes that Abiy, in order to garner "popular support and remove threats" targeted top TPLF officials breeding resentment among both the TPLF and the Tigrayans. In other related developments, all the major roads that connect Tigray with the Amhara Regional State were blocked and the border between Eritrea and Ethiopia (bordering Tigray), after it was briefly opened for few months, was closed again. This fact is equally true till present and will remain the same in the foreseeable future.

Zero-sum-game mindset grew bigger and bigger to the extent of defying the orders of the Federal Government. In reference to the condition of the TPLF between its substantial loss of power in Ethiopian politics of the year 2018 and the start of the conflict in November 2020, Crowe observes that the TPLF was engaged in "a dangerous game of spinning different stories depending on who it thought its audience was" (R. Crowe, 2021) and was pushing for war by "goading PM Abiy at every opportunity and spurning any attempt to make peace." (ibid).

The TPLF, after holding a regional election, was in an observable dilemmas: Unresolved conflicts with Eritrea and the perceived threat from Eritrea; mounting financial, economic, security and other pressures as well as isolation from the Federal Government and the resultant spiral of confrontation; and the decades-long hostility with the Amhara Regional State Government - all were the push factors to the TPLF's risk of taking a miscalculated pre-emptive attack due to security dilemma.

The above detailed three fundamental reasons sandwiched the TPLF-led Tigray Regional State Government between three grinding stones making it absolutely irreconcilable with the Federal Government, the Amhara Regional State Government (the domestic dimension) as well as with the Government of the State of Eritrea (an interstate dimension).
The final trigger was on November 4, 2020. When the security dilemma reached its highest peak, Amidst the above mentioned increasing frustrations and predicaments, the TPLF took a pre-emptive attack (ACLED, 2021) on Ethiopian Government Forces stationed in Tigray and afterwards Ethiopian Prime Minister Abiy Ahmed declared war on TPLF referring the pre-emptive attack as "trespassing the red line" (ibid) and gave order both to the Ethiopian National Defense forces as well as the forces from Amhara Regional State to eliminate both the "TPLF leadership and dismantle the political and security infrastructure of the former ruling force in Ethiopian politics.".

The TPLF also launched 13 rockets on Eritrea and set the legitimate reason for the involvement of the Eritrean Defense Forces into the conflict. (ibid) This uncalled-for attack on Eritrea was TPLF's attempt of not only to regionalize an internal problem of Ethiopia, but also to draw international community's attention. Though, the first objective brought Eritrea into the conflict, it didn't go beyond that. The second objective seems to have been partially successful for it resulted in diplomatic pressure from the US and the EU both on the Eritrean and Ethiopian governments that culminated with the withdrawal of the Eritrean forces from the conflict areas and the withdrawal of Federal Government forces from most part of Tigray except the western part that borders Sudan.

After three weeks of intensive military operations, the TPLF forces were weakened but not decidedly defeated in what the Government called it the 'Law Enforcement Operation.' As it has been mentioned above, the direct participants in the conflict are many. Furthermore, the larger the number of the protagonists, the harder it becomes to achieve sustainable peace. After eight months of bloody conflict and a subsequent devastation, the Federal Government under heavy pressure from the US and other Western countries, decided to a unilateral cease fire and at a fast pace withdrew its forces from Tigray. The withdrawal of the Federal Government forces from Tigray, unfortunately left the doors open for the perpetuation of the conflict within and outside the Tigray region.

\section{THE CHALLENGES FOR SUSTAINABLE PEACE}

As it has been mentioned earlier, the main argument of this paper is that unstable Tigray, compounded with the volatile nature of the Horn of Africa, poses a great challenge to the peace process between Eritrea and Ethiopia thus making sustainable peace too difficult to be achieved. Who are the Protagonists of the Conflict in the Tigray Region?

In order to understand the gravity and the complexity of the conflict and thereby understand the challenges to the realization of sustainable peace between Eritrea and Ethiopia, it is imperative to identify the main protagonists, their concerns, the dilemma they have and how their interests converge or diverge as related to the conflict in Northern Ethiopia. The international level aspect is also worth 
examining. Hence, this research identifies four protagonists to the conflict. Accordingly, there are three intra-state level protagonists in Ethiopia. Namely: The Federal Government of Ethiopia, the TPLF Forces, and the Amhara Regional State Government. At the inter-state level, there is the Government of the State of Eritrea. Additionally, the role of the Western countries in the conflict is worth discussing.

The Federal Government of Ethiopia: As of concerned the conflict in Tigray, the Federal Government has full support of the Amhara Regional State Government and its paramilitary forces. The Federal Government is so far in good terms with the Government of Eritrea and it can use this as deterrence to preclude the revival of the TPLF. Moreover, in the early days of the conflict, the Federal Government used advanced weaponry including drones, airplanes, and guided missiles (ACLED, 2021) that had decisive role in annihilating the military capability of the TPLF forces.

However, the Federal Government has been facing a number of challenges from within and outside. It was overstretched in dealing with a myriad of domestic challenges pertaining security, economy as well as political issues. Additionally, Ethiopia is on the verge of conflict with the Nile River downstream countries of Egypt and Sudan. In a similar token, Ethiopia has also been in a sporadic border clashes with Sudan - a clash that has palpable connections with Nile hydropolitics. The Federal Government, in the midst of all the above enumerated frustrating situations, in the end of June 2021, decided to withdraw its forces from Tigray in what it called it 'a unilateral ceasefire so that to give opportunity for the prevalence of peace in the Tigray region.' But, this decision left many issues unresolved.

The TPLF: Another main protagonist to the conflict in Tigray is the TPLF. Its objective, in different aspects, is diametrically opposed to the rest of the three protagonists of this conflict. The TPLF undeniably has a 17 years long history of conducting insurgency warfare and a more than quarter a century experience of governmental control. The TPLF despite it was engaged in rigorous military preparation for the inevitable military conflict and had decades long experience in military tactics and controlled huge military arsenal by launching an attack on the Northern command, according to ACLED, "it proved to be significantly weaker than the Federal Government throughout the conflict" (ACLED, 2021). Crowe witnesses that the TPLF had installed the 'image of militarily might' to the Ethiopian people (R. Crowe, 2021). Despite that, after the pre-emptive attack it took against the Ethiopian National Defense Forces and attacking Eritrea with rockets, in less than a month, the TPLF was militarily crushed and was put into disarray through a collaborative action taken by the Federal Government of Ethiopia, the Eritrean Government (in self-defense) as well as the Amhara Militia and Special Forces

The TPLF hoped that the conflict would be regionalized. In the final days of the outbreak of the outright conflict, the TPLF, in reference to Egypt and Sudan indirectly used to say they would join hands to help the TPLF if Eritrea supports the Ethiopian Government. But, the much sought support from the two Nile downstream countries did not materialize. Only after the end of the 17 days operation ended, Sudan went into border conflicts with Ethiopia.

The TPLF has been able to fill the vacuum created by the withdrawal of the Government forces from Tigray and claimed victory on what it calls them 'invaders'. The TPLF forces carried out continuous military operations inside Tigray and also expanded the conflict on neighboring regions of Afar and Amhara. Though, the TPLF could get 'the usual acceptance' by the majority of the Tigrayans, it is also expected to deal with a lot of issues of urgency in Tigray. There are millions of people who expect the TPLF to solve issues related to the provision of social service of all kind, dealing with food supply and administrative issues. Despite the acute shortage of all sorts of logistics it is facing, the TPLF is engaged in a continuous militarization of the youth in Tigray signifying its determination to the protraction of the conflict for the foreseeable future.

The Amhara Regional State Government and its Forces: The third intra-state protagonist in the conflict in Tigray is the Amhara Regional State government and its forces. The Amhara forces participated in the Tigray conflict since it started in November 2020 and their Regional State Government is still politically in full support of the action taken against the TPLF forces. They are determinedly engaged with what they call it 'fighting and regaining the lost territories' to Tigray. Though the Federal Government, out of the predicaments it is facing might have been appeasing the Amhara militias control the Wolkait and Raya areas, this may not bring any sustainable solution to the unswerving claim of the above mentioned lands by both the Tigrayans and the Amharas. The confrontation between the Amhara and Tigrayans are not only exclusively connected with territorial claim, but are also aggravated by historical grudge they had. Mogos pointed out that, the TPLF emphasized on what they call it the past privilege of the Amhara people during the military regime and summarily call the Amhara as "outlaws", "enemies" and in post 1991 TPLF-dominated Ethiopian State, subsequently disregarded the Amharas from "the economic windfalls of political power.” (Z. Moges, 2020)

The Government of Eritrea:_For the Government of Eritrea, the TPLF led Ethiopian Government was an existential threat, but as the TPLF-led Ethiopian Government incessantly tried to create a narrative about, it was not the vice versa. In reference to the ousted TPLF-led Government in Ethiopia, Crowe confirms that "to Eritreans, the message was 'overthrow their government', in the misplaced hope of weakening Eritrea and turn it into the TPLF's playground." (R. Crowe, 2021).

The Algiers Agreement of the year 2000 was a package of Agreement that included the cessation of hostilities and the obligation of accepting the EEBC's decision as a final and binding. When the verdict was given in April 2002, the 
Government of Eritrea unconditionally accepted it, whereas the TPLF-led Government of Ethiopia despite it said it accepted the decision, but later on called for 'dialogues' as a precondition, and continued to occupy sovereign territories of Eritrea. This not being enough, the TPLF-led Government of Ethiopia came with a policy of 'no peace, no war' as its guiding principle of foreign policy against Eritrea. The ' $n o$ peace, no war' policy on Eritrea made the continuation of the peace process impossible. It further saw the seeds to the precarious thinking of 'mutual exclusivity' between the then two governments.

Though, after the Algiers Agreement of 2000, no major war was fought between Eritrea and TPLF's Ethiopia, smaller scale clashes and skirmishes were not uncommon. When in November of 2020 Eritrea was attacked by 13 missiles by the TPLF forces, the Government of Eritrea was provoked to go into the conflict and acted in accordance to its right for selfdefense. At present, the TPLF may not be a threat to Eritrea as it used to be when it was in control of power in Ethiopia. But, for the years to come the characteristic features of the relations between the Government of Eritrea and the TPLF will be marked by confrontation, mutual distrust, suspicion and enmity.

At this time, the Government of Eritrea, to rule out any pressure that would come from the International Community, may not take any pre-emptive attack against the TPLF forces. Though any future conflict will definitely be asymmetric, this doesn't guarantee the preclusion of the outbreak of conflict any time in the near or distant future. The possibility of resurgence of conflict between the TPLF forces and the Eritrean Defense Forces will definitely make the hope for sustainable peace unattainable.

The 'what next' aspect of the conflict in Tigray and Northern Ethiopia in general is very intriguing. Having initially lost most of the military leverages it had, the TPLF has been attempting to create the narrative of 'liberating Tigray from invaders'. The TPLF is now in control of significant parts of the Tigray region as well as some parts of the Amhara and the Afar Regions. As an insurgency, the narrative of 'liberating Tigray from invaders' might attract 'the hearts and the minds' of the majority of the Tigrayans. But, waging a protracted war against many forces cannot by any means solve the progressively aggravating crisis.

The Federal Government and Amhara Forces have their respective concerns lest TPLF would revive. The posts June 2021 cycle of conflicts testify that the TPLF still has some military leverage. If the TPLF fully revives and augments military capability, it may pose a number of challenges: Firstly, it would attempt to regain 'its lost territories' to the Amharas. This possibility is real and will remain to be in the future. Secondly, taking into account the geographic importance of Tigray as a corridor between Northern Ethiopia and Eritrea, if the conflict continues let alone to achieve sustainable peace it would even be unrealistic to expect any meaningful cooperation between Eritrea and Ethiopia.
Thirdly, the TPLF even with its current limited capability will most probably continue to defy the sovereign rights of the Federal Government over Tigray and will attempt to rule Tigray as a quasi-independent state' indefinitely.

Amidst the above fragile and precarious situation the US and the EU want to intervene in what they call it as an 'advocacy to the under-dogs.' Looking back into the past, during its stay in power, the TPLF-led Ethiopian Government had strong relations with Western powers, especially with the US and the EU. The TPLF-led Ethiopian Government invaded Somalia in what the USA called it 'anti-terrorist mission'. Ethiopia's invasion of Somalia aggravated the long standing mutualsuspicion that prevailed between Ethiopia and Somalia.

As of concerned to Eritrea, the TPLF-led Ethiopian Government came up with a precondition for dialogue' and declared that it would not be abided by the Algiers Agreement and consequently obstructed the possible solution of the demarcation of the border between Eritrea and Ethiopia. The Western countries in general and the USA and EU in particular gave a deaf ear to Eritrea's unremitting call to play their due role in putting the Algiers's Agreement as well as the EEBC's ruling into effect. The failure of the USA and the EU to push for the implementation of the EEBC decision into effect complicated the possibility of finding a lasting solution for the border issues between Eritrea and Ethiopia. Demarcation of the border is still in limbo.

As witnessed from Libyan, Syrian, Somali, Yemeni and other conflicts, foreign intervention aggravated the domestic problems rather than it solved. What has been observed in the last consecutive months of the conflict, both the USA and EU have been exerting asymmetric pressure on the protagonists of the conflict. Amidst this debacle, hundreds of thousands of civilians have been displaced from conflict areas and this Internally Displaced Peoples (IDPs) are suffering from hunger, malnutrition, disease and all the war-related traumas. For the armed conflict is still going on, alleviating the travails of the civilians has become too difficult to manage.

\section{CONTEXTUALIZING THE CONCEPT OF SUSTAINABLE PEACE TO THE CONFLICT IN NORTHERN ETHIOPIA}

Miall etal, (2005) define conflict as "the pursuit of incompatible goals by different groups". So is the nature of the conflict in the Tigray Region of Northern Ethiopia. The overall crisis in Tigray is the reflection of a political realism that operates in an already hostile region where military solutions to political problems has become a norm. Is negotiation and peaceful settlement possible among all the parties involved in the conflict? Is waging a protracted war a viable option for TPLF where a small war-weary population of Tigray under a devastated economy to indefinitely fight against what the TPLF calls them 'enemies'? On the other side, geography is not in favor of the TPLF. After it lost the Wolkait lands to the Amhara militias, Tigray is now 'land locked' and denied of access to Sudan. Tigray is now 'doubly 
land locked' by the rest of Ethiopia and land locked in North by Eritrea.

Before analyzing the overall repercussion of the war on the domestic peace of Ethiopia as well as its inevitable connection with the attainment of sustainable peace with Eritrea, there is a need to discuss on what constitutes the concept of sustainable peace. In the context of the conflict in Tigray, one of the elements that are missing for the achievement of sustainable peace is that, there is a little space for conflict settlement. (Miall etal, 2005) warn that conflict settlement is not even an end by itself because there is possibility of deterioration into conflict where "conflicts that have reached settlements are often reopened later if conflict attitudes and underlying structural contradictions may not have been addressed".

(ACLED, 2021) warns that the presence of the Amhara forces in the controversial territories would aggravate the already bad relations among these two Regional States and "their presence provides a dangerous precedent." How long should the Amhara forces stay in these areas? This contested territory connects Tigray with Sudan, hence vital for TPLF forces for logistical, military, economic, and other purposes, hence will unquestionably be an area of continuous military engagement

Since the war started in November 2020, there have been reports from the Western media that the protagonists in the conflict had been allegedly committing gross violations of human rights against non-combatants. The selective sanctions imposed on both Ethiopian and Eritrean officials as well as the Amhara Regional State Government and TPLF officials portended that intervention was conceivable for the so called reason of 'peace building'. But, in reference to what actually happens on the ground, Das observes that peace building can lead into the breach of "sovereignty of other nations, ignoring territorial integrity, and demanding the right to act aggressively against governments that violate the Universal Declaration of Human Rights". (S. B. Das, 2004). Had it not been for the withdrawal of the Federal Government and the Eritrean Defense Forces from Tigray, the possibility that the USA and the EU to intervene in the conflict under the pretext of the 'responsibility to protect' would not be ruled out.

Another missing element for the attainment of sustainable peace between Eritrea and Ethiopia because of the conflict in Tigray is the obstacle lying ahead to carry on to peacemaking a situation that needs the preparedness of all parties involved in the conflict, in the words of (Miall etal,2005) to "reach agreement voluntarily." Das points out that peace building should begin from the requirement to end a conflict so that the foundations of justice can be established (S.B Das, 2004). For the Federal Government, negotiation with the TPLF has become difficult because the Federal Government has already included the TPLF among the list of terrorist groups. Hence, negotiating with the TPLF will have an adverse effect in the acceptance of the Government in the Ethiopian polity. This thorny issue puts the Government in a predicament between negotiating with TPLF and resuming the devastating war. So far, the withdrawal of the Federal Government from Tigray might have alleviated the pressure that would come from Western countries. As experience has shown time and again, this phenomenon will not lead to the containment of the conflict.

Because of the above facts, at this time, conflict resolution seems unattainable. Mial etal explicate that conflict resolution entails that "behavior is no longer violent, attitudes are no longer hostile, and the structure of the conflict has been changed."'(Mial etal, 2005). Unfortunately, the behavior of the protagonists has not ceased up to be violent, neither their attitude has become approachable nor the structure of the conflict has changed. The TPLF leadership, after they recontrolled the regional capital of Mekelle visibly witnessed that they are still in a war-footing with all the rest protagonists of the conflict. The TPLF forces, in their attempt to gain military leverage, have currently expanded the conflict into the neighboring regions of Afar and Amhara. They constantly and consistently are reiterating that no peace is conceivable with all protagonists of the conflict so far Tigray 'didn't regain its lost territories' to Eritrea as well as to the Amhara region. Under the current situation, the peace process that started back in 2018 has been deleteriously obstructed and the hope of achieving sustainable peace is indeed challenging. As has been mentioned earlier, the conflict in Tigray will not remain as a domestic issue of Ethiopia, but also will be a stumbling block to the achievement of sustainable peace between Eritrea, Ethiopia and beyond. D. Nagar and M. Paterson (2013) observe that "regional considerations often have a major bearing on whether or not peace building efforts succeed", so is true in the environment of the Horn of Africaa region where "hope and peace are rare commodities". (Kassa G., 2004).

\section{CONCLUSION}

Under the current complicated situation, no feasible solution is at hand. The TPLF has now become mutually exclusive with the Federal Government, Amhara Regional paramilitaries and the Government of Eritrea. And all the three protagonists do not want the resurgence of the TPLF. All the elements that give impetus to sustainable peace are non-existent. No government would be voluntarily and whole-heartedly negotiate with a group it calls 'a terrorist'. Likewise, the antagonism between the Eritrean government and the TPLF is intensifying. The claim and control of the 'lost territories' of Wolkait and Raya is and will remain to be, the main concern for Amhara Regional Government and this seems irreconcilable to what the Tigrayans claim to be 'their land'. As history witnesses, any foreign intervention and pressures will not bring any meaningful solution to the conflict in Tigray. The long festering wounds of the continuous conflict have not been healed, instead are being aggravated leaving little space for reconciliation, confidence building and mutual trust. Unfortunately, intermittent conflicts may dominate the near future. Unstable Tigray will continue to pose a far- 
reaching bearing on the peace process between Eritrea and Ethiopia and thus making the achievement of sustainable peace very challenging.

\section{REFERENCES}

[1] Ahmed Soliman (2019). Can Abiy Ahmed Continue to Remodel Ethiopia?p.12APRIL 019: https://www.chathamhouse.org/aboutus/our-people/ahmed-soliman

[2] Armed Conflict Location \& Event Data Project (2021): Red Lines: Upheaval and Containment in the Horn of Africa: Author(s): Armed Conflict Location \& Event Data Project Armed Conflict Location \& Event Data Project: Accessed: 27-05-2021 16:27 UTC p: $1-30$

[3] Christopher E. Miller(2005) A Glossary of Terms and Concepts in Peace and Conflict Studies. $2^{\text {nd }}$ ed. . University of Peace.

[4] Dawn Nagar and Mark Paterson (2013). Peace and Security. South Africa in Southern Africa Centre for Conflict Resolution. https://about.jstor.org/terms . Downloaded from 222.27.72.45 on Thu, 27 May 2021 16:13:55 UTC

[5] Hugh Miall, Oliver Ramsbotham, Tom Woodhouse(2005). Contemporary Conflict Resolution: The Prevention, Management and Transformation of Deadly Conflicts 2005 .Blackwell Publishing Professional.

[6] Kassu Gebremariam (2004). Peace building in the Horn of Africa. The Role of Africa's Regional Organization. In Tom Keating \& W. Andy Knight (editors) .Building Sustainable Peace. The University of Alberta Press. 2004 p: 189
[7] Kidane Mengisteab (2011). Critical Factors in the Horn of Africa's Raging Conflicts. Discussion Paper 67. Nordiska Afrikainstitute, Upssala, 2011. P-12.

[8] Martin Plaut (2021) Eritrea in the Tigray war: What we know and why it might backfire. JANUARY 8, 2021 https://africanarguments.org/author/martin-plaut

[9] Reuters: (10 November 2020) https://www.the-star.co.ke/thestar/news/africa/

[10] Robert Crowe (2021). Al Jazeera Appears to Lend Itself to TPLF Disinformation: African Medias. Posted on March 5, 2021https://www.africanmedias.com/horn-of-africa-al-jazeeraappears-to-lend-itself-to-tplf-disinformation/?lang=en

[11] Satya Brata Das (2004) Sustainable Peace Who Pays the Price? In Tom Keating \& W. Andy Knight (editors) Building Sustainable Peace. The University of Alberta Press.

[12] Temesgen Kahsay (2021) As a Tigrayan, my bond with Ethiopia feels beyond repair. JANUARY 12, 2021 https://africanarguments.org/author/temesgen-kahsay/

[13] Yonatan T. Fessha (2020)Why Ethiopia's Conflict in Tigray was Avoidable. The Africa Report. Posted on Tuesday, 1 December 2020 17:30

[14] Zola Moges (2020): Ethiopia: Defining Amhara Nationalism for a Better country. https://www.theafricareport.com/subscribe/?checkout origin url= https\%3A\%2F\%2Fwww.theafricareport.com\%2F43182\%2Fethiop ia-defining-amhara-nationalism-for-a bettecountry\%2F\&checkout origin post id $=43182$ Posted on Sunday, 27 September 2020 12:19, updated on Wednesday, 4 November 2020

$11: 55$ 